\title{
Clinical relevance of androgen receptor alterations in prostate cancer
}

\author{
Emma Jernberg, Anders Bergh and Pernilla Wikström \\ Department of Medical biosciences, Umeå University, Umeå, Sweden
}

\begin{abstract}
Prostate cancer $(\mathrm{PC})$ remains a leading cause of cancer-related deaths among men worldwide, despite continuously improved treatment strategies. Patients with metastatic disease are treated by androgen deprivation therapy (ADT) that with time results in the development of castration-resistant prostate cancer (CRPC) usually established as metastases within bone tissue. The androgen receptor (AR) transcription factor is the main driver of CRPC development and of acquired resistance to drugs given for treatment of CRPC, while a minority of patients have CRPC that is non-AR driven. Molecular mechanisms behind epithelial AR reactivation in CRPC include AR gene amplification and overexpression, $A R$ mutations, expression of constitutively active $A R$ variants, intra-tumoural and adrenal androgen synthesis and promiscuous $A R$ activation by other factors. This review will summarize AR alterations of clinical relevance for patients with CRPC, with focus on constitutively active AR variants, their possible association with $A R$ amplification and structural rearrangements as well as their ability to predict patient resistance to AR targeting drugs. The review will also discuss AR signalling in the tumour microenvironment and its possible relevance for metastatic growth and therapy.
\end{abstract}

\author{
Correspondence \\ should be addressed \\ to P Wikström \\ Email \\ pernilla.wikstrom@umu.se
}

\section{Introduction}

Prostate cancer (PC) is one of the most common forms of cancer and a leading cause of cancer-related deaths in men worldwide (1). Androgens regulate normal and malignant prostate tissue growth via activation of androgen receptor (AR) signalling in epithelial and stroma cells. Androgen deprivation therapy (ADT) is the standard therapy for locally advanced and metastatic PC, including surgical and chemical castration that deprives tumour cells of testicular androgens and thereby reduces tumour growth. Although ADT is initially effective in most patients, the disease progresses within a few years into an incurable and lethal stage of castration resistance. Castrationresistant prostate cancer (CRPC) is usually established as bone metastases, but also as soft tissue metastases and through local recurrence. The AR in tumour epithelial cells is active in nearly all CRPC tumours despite castrate levels of circulating testosterone $(2,3)$, while a minority of CRPC metastases seem to be non-AR driven $(4,5)$. Mechanisms leading to epithelial AR reactivation in CRPC include, AR amplification and overexpression, AR mutations, expression of constitutively active AR variants, intra-tumoural androgen synthesis and promiscuous AR activation by other factors, as extensively reviewed previously $(6,7)$. Thus, the AR has for a long time been the main target in the treatment of advanced PC, and the combination of castration therapy with 1st-generation antiandrogens (flutamide, nilutamide and bicalutamide) reduces the risk of PC death by $10-30 \%$ compared to castration alone (8). Through the development of the 2nd-generation AR antagonists such as enzalutamide and

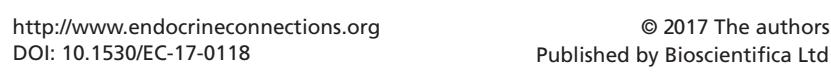


apalutamide and the steroidogenesis inhibitor abiraterone acetate, CRPC patients show further improved survival $(9,10,11)$. However, not all CRPC patients respond to those AR-targeting drugs, and drug resistance also develops with use. This review will summarize AR alterations of clinical relevance for patients with CRPC, with focus on constitutively active AR variants, their possible association with $A R$ amplification and structural rearrangements as well as their ability to predict patient resistance to AR-targeting drugs. It will also discuss AR signalling in the tumour microenvironment and its possible relevance for metastatic growth and therapy.

\section{The AR structure, activation and function}

The $A R$ gene is located at chromosome X (Xq11-12) and contains eight exons encoding a $110 \mathrm{kDa}$ protein. The AR protein consists of a $\mathrm{NH}_{2}$ terminal transactivation domain (NTD, encoded by exon 1), a DNA-binding domain (DBD, encoded by exons 2 and 3), a hinge region ( $\mathrm{H}$, encoded by the $5^{\prime}$ portion of exon 4) that contains the nuclear localization signal (NLS) and a ligand-binding domain (LBD/CTD, encoded by the remaining exon 4 through exon 8) (12). Testosterone and dihydrotestosterone (DHT) bind to the $\mathrm{LBD}$ of the $\mathrm{AR}$ and induce a conformational change of the protein that leads to dissociation of chaperone proteins and exposes the NLS in the hinge region. The AR dimerizes and translocates to the nucleus where it interacts with transcriptional co-regulators, binds to androgen response elements (ARE) and regulates the transcriptional output of hundreds to thousands of androgen-regulated genes depending on cell type. In prostate epithelial cells the AR regulates the expression of $N K X 3.1$ and FOX family transcription factors, IGF1R, UBE2C, UGT2B15, KLK3, TMPRSS2, FKBP5 and other genes controlling cell growth, differentiation and function in the normal prostate and during PC growth and progression (13).

\section{Overexpression of the AR in CRPC}

Increased AR expression is consistently seen in tumour epithelial cells during development of CRPC (2), whereas a loss of AR signalling is generally observed in the primary tumour and metastasis stroma (14). Overexpression of the AR in tumour epithelial cells could be a result of $A R$ gene amplification as described below, but is probably also an instant response to castration as androgens normally

http://www.endocrineconnections.org DOI: 10.1530/EC-17-0118 supress $A R$ transcription in prostate epithelial cells $(15,16$, 17). $A R$ amplification is the most frequent genetic alteration reported for CRPC tumours, as observed in up to $50 \%$ of the cases $(18,19,20,21)$. This stands in contrast to untreated primary prostate tumours (22) where $A R$ amplification is rarely detected, suggesting that $A R$ amplification is an adaptive response to ADT. $A R$ amplification has been linked to $A R$ overexpression in clinical samples and experimental systems and thereby to sensitising tumour epithelial cells to low androgen levels $(23,24)$. Detection of $A R$ amplification in circulating tumour cells (CTCs) and circulating tumour DNA (ctDNA) isolated from patients with CRPC has been associated with therapy resistance to the AR antagonist enzalutamide and the CYP17 blocker of steroidogenesis, abiraterone acetate $(25,26)$.

\section{Activating AR mutations in CRPC}

AR signalling in CRPC tumour epithelial cells could also be caused by activating $A R$ point mutations. Such mutations are very rare in untreated PC, but detected in 15-20\% of CRPC patients $(19,20,27)$ and in up to $40 \%$ of CRPC patients treated with AR antagonists (28). Activating $A R$ point mutations generally affect the c-terminal LBD, while about one-third occur in the transactivating NTD $(29,30)$ resulting in broaden ligand specificity and AR activation by weak adrenal androgens and other steroid hormones, including DHEA, progesterone, oestrogen and glucocorticoids as well as in turning antagonists into agonists, as recently reviewed in (31) and summarized in this article in Table 1 . The first and most frequently identified $A R$ point mutation is the flutamide-driven T878A mutation $(32,33,34,35)$, while W742C and $\mathrm{H} 875 \mathrm{Y}$ also have been reported after treatment with firstgeneration AR antagonists $(36,37,38,39,40,41)$. Also, the use of 2nd-generation AR antagonists and the CYP17 inhibitor abiraterone acetate seems to select for activating $A R$ mutations. The F877L-mutated $A R$ has been detected in cfDNA from CRPC patients progressing on enzalutamide or apalutamide $(25,42)$ and is, accordingly, activated by flutamide, enzalutamide and apalutamide in experimental models systems for PC $(38,42,43,44)$. The F877L mutation seems to be a rare event as it was not detected in a study of 150 CRPC metastases, of which about a half of the patients were pre-treated with enzalutamide (20). Enzalutamide and ARN509 (apalutamide) have agonist effects also on the H875Y, T878A and T878S mutations, all detected in CRPC patients (38), but acquired resistance to those 
Table 1 Activating androgen receptor mutations recurrently identified in CRPC.

\begin{tabular}{l} 
Mutation \\
\hline T878A \\
W742C \\
H875Y \\
F877L \\
L702H
\end{tabular}

\section{Aberrant effect}

Activated by progesterone, estrogen, flutamide, bicalutamide, enzalutamide and apalutamide

Activated by bicalutamide, flutamide

Activated by estrogen, progesterone, glucocorticoids, adrenal androgens, bicalutamide, flutamide, enzalutamide and apalutamide

Activated by flutamide, apalutamide and enzalutamide

Activated by glucocorticoids
References

$(25,32,33,34,35,38,47)$

$(36,37,38,39)$

$(25,35,36,37,38,40,41)$

$(25,38,42,43,44)$

$(26,38,50,51,52)$ drugs may primarily depend on increased expression of the glucocorticoid receptor and AR bypass $(45,46)$ or the induction of constitutively active AR variants, as discussed below. The T878A, H875Y and the $L 702 H$ mutations have been observed in CRPC patients progressing during abiraterone treatment and associated with either the increased progesterone levels obtained after CYP17 inhibition $(25,47,48,49)$ or with the co-administration of exogenous glucocorticoids given to compensate for significantly reduced cortisol levels $(26,50,51,52)$. The activating AR point mutations T877A, L702H and H875Y have been detected in cfDNA from patients with CRPC and shown to be associated with resistance to abiraterone and enzalutamide $(25,26,42,49)$.

\section{Structural AR gene alterations in CRPC}

In addition to $A R$ amplification and point mutations in tumour epithelial cells, diverse structural $A R$ alterations including deletion, duplication, inversion and translocation events have been reported; first for experimental model systems of CRPC and then for a substantial fraction of clinical CRPC samples (53, 54, $55,56,57)$. By targeted paired-end DNA sequencing of the coding and non-coding $A R$ region in 30 soft tissue metastases collected at rapid autopsy of 15 CRPC patients, structural $A R$ alterations were demonstrated in 10/30 cases (6/15 patients), while no alterations were observed in the 21 hormone-naïve primary prostate tumours analysed (56). In another study, cell-free DNA was analysed from 30 CRPC patients and 50\% were found to have structural $A R$ alterations (57). Together, these studies show that the AR gene structure is frequently altered in CRPC and, moreover, that sub-clonal heterogeneities may exist within and in-between patients. Possible associations between structural $A R$ alterations and the generation of constitutively active, truncated AR variants as well as their prognostic and therapy-predictive value will be discussed in more detail below.

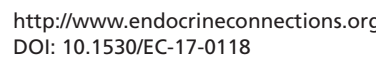

\section{Constitutively active AR variants in CRPC}

The first truncated AR variants (AR-Vs) with subsequently proved gain of function were identified in 22Rv1 cells due to the presence of $75-80 \mathrm{kDa}$ AR immunoreactive species that were initially thought to be proteolytic fragments of wild-type AR (ARwt) (58). However, later work demonstrated that RNA interference (RNAi) targeting the LBD of the AR reduced expression of the full-length $\mathrm{AR}$, but not of the shorter isoforms (59). This suggested that the truncated AR-Vs were not products of ARwt, but instead derived from unique RNAs. To date, over 20 truncated AR-Vs have been identified in human PC cell lines, xenografts and clinical specimens and some have proven to be constitutively active, i.e. they are able to translocate into the nucleus and initiate transcription without the need for ligand binding $(20,60,61)$.

In clinical samples, truncated AR-Vs has been detected in the normal prostate, in primary prostate tumours and in non-treated PC metastases, but highly increased levels have been seen only in CRPC $(20,62,63,64,65,66,67)$ and mainly in association with AR amplification $(21,57)$.

\section{Nuclear translocation and constitutive activity of AR variants}

Gain-of-function AR-Vs lack portions of the LBD and instead have divergent COOH-terminal extensions encoded by unique transcripts. Some AR variants are recurrently found in CRPC and have been described as constitutively active, such as the AR-V7 (also termed AR3) $(62,63)$, AR-V567es (also termed AR-V12) $(63,64)$ and AR-V3 $(59,63)$, whereas others (i.e. AR-V1 and AR-V9) seem to be conditionally active, depending on cellular context $(68,69)$ (Table 2). The majority of the AR-Vs identified today harbour the same NTD and DBD as the ARwt. Between the DBD and the LBD is the hinge region, which harbours the canonical NLS required for the nuclear localization of the ARwt following ligand binding. In contrast to the canonical AR signalling pathway, the

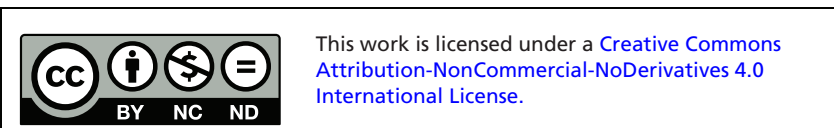


Table 2 Gain-of-function AR variants recurrently identified in CRPC.

\begin{tabular}{|c|c|}
\hline Variant & Transcriptional activity \\
\hline AR-V7 (AR3) & Constitutive \\
\hline $\begin{array}{l}\text { AR-V567es } \\
\text { (AR-V12) }\end{array}$ & Constitutive \\
\hline AR-V3 & Constitutive \\
\hline AR-V1 & $\begin{array}{l}\text { Dependent on cell } \\
\text { context }\end{array}$ \\
\hline AR-V9 & $\begin{array}{l}\text { Dependent on cell } \\
\text { context }\end{array}$ \\
\hline
\end{tabular}

Clinical relevance
- Resistance to ADT, enzalutamide and abiraterone
- Short time to disease relapse after radical prostatectomy and
more rapid progression to CRPC
- Poor PSA response, short progression-free survival, short
overall survival and short cancer-specific survival of CRPC
patients
- Resistance to ADT
- Enriched in CRPC and metastases
- Shortance to ADT and abiraterone
- Enriched in CRPC and metastases
- Resistance to ADT and abiraterone
- Short progression-free survival of CRPC patients

References

$(48,62,63,65,66,69$,

$103,104,105,107$ )

$(64,65,68,106)$

$(57,59,63,69)$

$(63,65,68,71)$

$(68,69)$

mechanisms enabling AR variants to enter the nucleus are less clear. Depending on the presence/absence of the hinge region, some constitutively active AR variants (i.e AR-V567es) express a NLS, whereas others (i.e. AR-V3, AR-V7, AR-V9) do not $(59,62,63,64,68)$. Studies have suggested that a NLS-like signal located in the unique $\mathrm{COOH}$-terminal extension allows the NLS-negative AR variants to enter the nucleus $(63,68)$. However, Chan and coworkers reported that a truncated AR molecule consisting only of the AR NTD/DBD core exhibits a basal level of nuclear localization sufficient for ligand/ androgen-independent transcriptional activity regardless of whether they harbour the exon 4-encoded NLS or NLSlike $\mathrm{COOH}$-terminal extensions (70).

Two of the most well characterized AR-Vs, AR-V7 and AR-V567es, have demonstrated constitutive activity in different cell systems. The AR-V7 was originally discovered and functionally tested in the androgenindependent 22Rv1 and CWR-R1 cell lines (59, 62, 63). Specific depletion of endogenous AR-Vs in 22Rv1 cells and overexpression of AR-V7 in LNCaP cells resulted in decreased and increased growth, respectively, under androgen-depleted in vitro and in vivo conditions $(59,62$, 71). AR-V567es was first identified in the LuCaP 86.2 and 136 PC xenografts, and found to increase proliferation of LNCaP cells in the absence of androgen as well as to enhance proliferation in response to very low levels of androgen (64). In preclinical in vivo models, expression of AR-V567es and AR-V7 has been shown to increase after castration and to confer both primary and acquired resistance to abiraterone and enzalutamide $(64,72,73$, $74,75,76,77,78)$. A recent paper furthermore displays constitutive activity of AR-V9 when transfected into the AR-positive LNCaP and the AR-negative DU145 cell lines (69), while AR-V9 was previously reported as conditionally active due to transfected activity into LNCaP but not PC-3 cells (68). Conditionally active AR-Vs may depend on the expression of certain co-regulators, as discussed below in relation to the AR-V transcriptome.

\section{The transcriptome of constitutively active AR variants}

The wild-type AR is well known to mediate its transcriptional effects after forming homodimers in response to ligand binding. Whether or not AR-Vs also form homodimers or possibly heterodimers with the ARwt needs to be further clarified. Heterodimers of ARwt and AR-V7 have not been detected in the 22Rv1 or the CWRR1 cell line $(58,62,79)$, while AR-V567es has been shown to co-immunoprecipitate with ARwt in lysates from a patient-derived xenograft, indicating that AR-V/ARwt complexes are able to form (64). A recent study by $\mathrm{Xu}$ and coworkers characterized protein-protein interactions between AR-V7, AR-V567es and the ARwt in the PC3 cell line (80). They concluded that, in PC3 cells, both AR-V7 and AR-V567es could form heterodimers with ARwt and were also able to form homodimers in the absence of androgens. The hetero-dimerization of AR-Vs and ARwt was mediated by NTD and CTD interactions (NTD of AR-Vs and CTD of ARwt) and by DBD-to-DBD interactions, whereas AR-V homodimerization was mediated by DBDto-DBD interactions only. PC3 cells with mutant AR-Vs that prevented DBD-DBD homodimerization abolished the ability of AR-Vs to induce transcription and to induce castration-resistant cell growth, suggesting that dimerization was required for AR-V function. In an earlier study where ARwt, AR-V7 and AR-V567es were ectopically expressed in COS-7 cells, AR-Vs could activate ARwt in the absence of androgen and facilitated nuclear translocation and transcriptional activity (75). The same study showed 
that in 22Rv1 cells the PSA promoter was co-occupied by AR-V7 and ARwt, whereas the promoter of the UBE2C gene was bound only by AR-V7. From these results and with the knowledge that also when expressed at high levels in clinical samples, the AR-V seems to be co-expressed with the ARwt, it can be speculated that AR-V homodimers and AR-V/ARwt heterodimers form in parallel and have the potential to regulate different sets of target genes (75).

AR-Vs may transcribe canonically androgen-regulated genes or a unique subset of genes or possibly both. In clinical bone metastases, we found high AR-V7 levels to be associated with expression of certain canonical AR genes, such as UBE2C, CCNA2, UGT2B17 and C-MYC, but not with others (KLK3, KLK2, NKX3-1, TMPRSS2 and FKBP5) (65). Many functional studies have been performed to evaluate the AR-V transcriptome by ectopically expressing or knocking-down AR-Vs in different cell lines, but unfortunately without consistency $(63,64,73,81)$. Some studies have suggested sets of AR-V7-regulated genes such as $A K T 1$ (62) and genes associated with the M-phase cell cycle progression, including above-mentioned UBE2C and CCNA2 (82) and the FOXA1-repressed target genes EDN2 andETS2 (83). In contrast, chromatin immunoprecipitation sequencing (CHIP-seq) of the R1-D567 and R1-AD1 cell lines showed a high concordance between the AR-V567es and ARwt cistromes, with chromatin sites engaged by both AR-V567es and ARwt including UBE2C, CCNA2, EDN2 and ETS2 (84). UBE2C and CCNA2 were also not unique targets for AR-Vs in the 22Rv1 and CWR-R1 cell lines, but also regulated by the ARwt $(73,81)$. Importantly, a recent paper highlighted frequent parallel synthesis of AR-V7 and AR-V9 in PC cell lines (and in patients) due to a tandem site for the cryptic exons giving rise to alternative splicing of those two variants (69). Without previous knowledge of this tandem site, recent studies performed to specifically quantify or knock-down the AR-V7 transcript may have been targeting the AR-V9 in parallel. The AR-V transcriptome therefore need to be further refined by precise knock-down of AR-V7 without affecting AR-V9 levels and vice versa. Furthermore, with specific antibodies now available for AR-V7, AR-V9 and other AR-Vs more specific immunohistochemistry and CHIP-seq studies can be performed in the future.

It should also be considered that the AR-V transcriptome may depend not only on the specific AR-V, but also conditionally on the cell type and the expression of specific AR co-regulators. The ARwt harbour activating functional domains both in the NTD (AF-1, Tau1 and Tau5/AF5) and the LBD (AF-2) and, while the AF-2 site is lost in LDB-truncated AR-Vs, co-factors binding to the NTD could theoretically affect the activity of most AR-Vs, as recently reviewed in (85). Also co-factors that in the presence of androgens interact with the LBD of ARwt have been shown to enhance the activity of AR-Vs, probably by interaction through alternative domains. One interesting example is the more potent recruitment of PI3K/AKT phosphorylated MED1 to the enhancer region of the UBE2C promoter by AR-V567es compared to ARwt $(86,87$, 88 ), something that may explain the high level of UBE2C expression seen in AR-V-driven tumours. The pioneer factors FOXA1 and GATA2 co-localize with both ARwt and AR-Vs on chromatin and increase their activities $(88,89)$, and FOXA1 was shown to be obligate for the proliferative effect of AR-Vs in CWR22Rv1 cells (90). GATA2 induces $A R$ transcription (and thus potentially also AR-V expression) and as ligand-activated ARwt normally should repress GATA2 expression, it may be that GATA2 increases both expression and activity of ARwt and AR-Vs in androgendeprived CRPC $(89,91,92,93)$. Further studies are needed to decipher how co-regulators, activators and repressors, interact with and facilitate the activity of different AR-Vs.

\section{Origin of truncated AR variants}

The molecular mechanisms mediating increased levels of truncated AR-Vs in CRPC tumour epithelial cells still need to be clarified. While most transcripts coding for truncated AR-Vs seem to arise from alternative splicing due to incorporation of cryptic exons in the $A R(59,62$, 63) some may also be derived from exon skipping or by genetic deletions/rearrangement $(55,64)$. The enrichment of AR-Vs in CRPC may be related to the increased transcription of $A R$, observed in prostate epithelial cells after castration and in $A R$ amplified tumours, or to structural $A R$ rearrangements and/or aberrant expression of specific splice factors, as discussed below. Another possible explanation for the observed enrichment of AR-V in CRPC may be a concomitant reduction of micro-RNAs normally downregulating AR and AR-V levels $(94,95)$.

The abundance of specific splice variants may be controlled both by gene transcription rate and by splice factor recruitment to the pre-mRNA during the process of alternative splicing $(96,97,98)$. An early observation was that specific inhibition of the ARwt protein in PC cell lines (via castration, antiandrogen treatment or siRNA) led to increased expression of AR-V7 but also of ARwt, and DHT treatment lead to decreased expression of both AR-V7 and ARwt $(77,82)$. Enzalutamide treatment was 
shown to increase transcript levels of ARwt and AR-V7 and, furthermore, to increase the recruitment of the splicing factors to the binding sites near the $3^{\prime}$ terminal cryptic exon of AR-V7. The ASF/SF2 and U2AF65 splicing factors were shown to be critical for the formation of AR-V7, while the knockdown of the hnRNPA1 splicing factor reduced levels of both the AR-V7 and the full-length AR transcript (99). Another study, however, reported enhanced recruitment of hnRNPA1 to the AR-V7 splicing sites in enzalutamide-resistant cells, while no change in recruitment of hnRNPA1 to the full-length AR mRNA was observed (100). The authors further provided evidence that alternative splicing and generation of AR-V7 might be regulated by hnRNPA1 through NF-kB2/p52 and c-Myc. Another study implicated a role for the molecular chaperone HSP90 in the splicing of AR-V7, as HSP90 inhibition in PC cells with endogenously expression of AR-V7 lead to the disruption of AR-V7 splicing and reduced AR-V7 mRNA levels (101). Thus, increased transcription rate and subsequent recruitment of certain splice factors might be the link between castration, AR amplification and the enrichment of AR-Vs in relation to ARwt in CRPC cases.

Certain structural AR gene alterations such as a $8.5 \mathrm{~kb}$ deletion of the 5, 6 and 7 exons as well as a genomic inversion of the corresponding part have been identified and provided mechanisms for AR-V567es synthesis in the LuCaP 86.2 and LuCaP 136 xenograft models, respectively $(54,55)$. Diverse structural $A R$ alterations have further been suggested to increase the probability for occurrence of alternative splicing; both in experimental models and clinical samples of CRPC. The 22Rv1 cell line harbours a $35 \mathrm{~kb}$ intragenic tandem duplication containing AR exon 3 and several 3' cryptic exons (CEs), including the terminal exon CE3 of AR-V7 and as subsequently shown also the CE5 of AR-V9 $(53,69)$. Structural $A R$ events involving exon 3 were in parallel observed in clinical samples from CRPC patients by Li and coworkers. The high expression of AR-V7 in the CWR-R1 cell line was later linked to a $48 \mathrm{~kb}$ deletion in AR intron 1 (54).

More recent studies have strengthened the associations between $A R$ amplification, structural $A R$ alterations and the expression of truncated AR variants in clinical samples, by targeting DNA analysis of the $A R$ and AR-V7 mRNA levels in metastatic tissue and liquid biopsies from CRPC patients $(21,56,57)$. The studies by Henzler and De Laere further refined that $A R$ rearrangements can occur in the context of $A R$ amplification or at normal $A R$ copy number and, furthermore, that some $A R$ structural variations seem to be associated with the presence of AR-V expression, whereas others are not. Further studies are needed to elucidate the functional importance of diverse structural $A R$ alterations and the regulation of the RNA splicing program that seems to favour AR-V synthesis and/or stability as a survival strategy for PC cells in response to ADT.

\section{Clinical relevance of truncated AR variants}

As described earlier, AR-Vs can be detected in benign prostate tissue, hormone-naïve and CRPC, with the most frequent and highest expression detected in CRPC samples $(20,62,63,64,65,66,67)$. AR-V7 is believed to be clinically relevant as it is frequently observed and abundantly expressed. In an early study of bone metastases from CRPC patients, we reported high AR-V7 mRNA expression to correlate with high AR-V protein levels and particular poor prognosis (65). In a recent study analysing AR-Vs in CTCs from CRPC patients, AR-V7 was reported as the most frequently occurring variant (12/15 patients), while the second most frequent variant, AR-V3 was more abundantly expressed (57). Expression of AR-V7 in primary prostate tumours has been shown to correlate with shorter time to disease relapse after radical prostatectomy $(62,63)$ and more rapid progression to CRPC (66). High levels of AR-V7 mRNA or nuclear AR-V7 protein or detectable expression of AR-V567es mRNA in CRPC tumours have been associated with poor patient survival $(65,66,67)$. Thus, AR-V7 and possibly also other variants appear to be associated with the development of lethal PC.

In clinical CRPC specimens, individual AR-V transcripts are always co-expressed with the full-length AR transcript, but they are usually much less abundant (20). Nevertheless, metastasis levels of the AR-V proteins are comparable to that of the ARwt receptor in a substantial fraction of CRPC patients $(65,102)$. In samples where the AR-V7 mRNA levels constituted only $0.4-1 \%$ of the full-length AR mRNA levels, we observed a relative median AR-V protein expression of $32 \%$, as determined by immunoblotting analysis using an antibody targeting the N-terminal of the AR. This could indicate post-transcriptionally stabilization of AR-Vs in selected CRPC tumours. Accordingly, in vitro studies have suggested that the AR-V7 protein may be more stable than the wild-type AR (101).

\section{AR-Vs as therapy-predictive biomarkers}

In a series of papers, detectable levels of AR-V7 and some other AR-Vs have been shown to predict poor 
response to AR targeting therapies, as discussed below. In a prospective clinical study, Efstathiou and coworkers evaluated the prognostic impact of AR-V7 expression in metastasis biopsies. By using immunohistochemistry on FFPE specimens, AR-V7 protein levels were analysed in 60 patients with bone metastatic CRPC before and 8 weeks after enzalutamide treatment. The presence of AR-V7 staining was associated with primary resistance to enzalutamide (103). Sampling of metastasis biopsies from therapy responding and non-responding patients is extremely important to enable research studies where we can gain knowledge about the biology of CRPC. However, as CRPC metastases are primarily found in the bone marrow and in the skeleton and as sampling of such metastasis biopsies is logistically challenging, non-invasive liquid biopsies like CTCs and cfDNA may be preferred in studies aiming at monitoring the whole tumour burden of a patient.

In 2014, Antonarakis and coworkers measured mRNA expression of AR-V7 in CTCs from metastatic CRPC patients before starting treatment with enzalutamide or abiraterone. The presence of AR-V7-positive CTCs correlated with lower PSA response rate, shorter progression-free survival and reduced overall survival in both treatment groups (104). These findings were supported by another prospective study were the AR-V7 mRNA levels in CTCs were significantly higher in patients who had previously received abiraterone or enzalutamide compared to those who had not (48). Recently, Antonarakis and coworkers confirmed and extended their previous results by evaluating the predictive value of AR-V7-positive CTCs in a cohort of 202 CRPC patients starting enzalutamide or abiraterone treatment. Patients without detectable CTCs were found to have the longest progression-free and overall survival, while patients with AR-V7-positive CTCs showed the worst prognosis (105). The AR-V7 and AR-V567es transcripts have also been detected in CRPC patients by evaluation of whole blood $(106,107)$. In a retrospective study of 132 CRPC patients treated with either abiraterone or enzalutamide, KLK3 (PSA) and AR-V7 mRNA levels in whole blood were associated with short time to treatment failure and short overall survival (107). Novel data by Kohli and coworkers, however, provides evidence that previous measurements of the AR-V7 transcript using PCR-based assays may have misleadingly detected also the AR-V9 transcript due to a common 3' cryptic exon (69). By evaluating available RNA sequence data from metastases from two different CRPC cohorts, they found AR-V9 and AR-V7 mRNA levels in CRPC metastasis tissue to be highly correlated. They furthermore found metastasis levels of AR-V9 together with AR-V3 to be significantly associated with short progression-free survival in 78 CRPC patients treated with abiraterone, while AR-V7 levels were borderline increased in poorly responding patients (69).

The role of AR-Vs in therapy resistance may not be limited to androgen-directed therapies. Preclinical studies have indicated that AR-Vs might also contribute to taxane resistance, although results are somewhat inconclusive (108, 109). In contrast, two prospective clinical trials showed no association between detection of AR-V7 in CTCs and primary resistance to taxane chemotherapy (110, 111). Instead, the clinical outcome for AR-V7positive patients appeared to be better with taxanes than with AR-targeted therapies (110). This concept was also confirmed in a study where nuclear expression of the AR-V7 protein was measured in CTCs from 161 CRPC patients before treatment with antiandrogens or taxane chemotherapy. Patients with AR-V7-positive CTCs prior therapy exhibited superior clinical outcome with taxanes compared with antiandrogen therapy (112). These studies thus suggest that AR-V7 may serve as a predictive biomarker favouring docetaxel and cabazitaxel chemotherapy over treatments targeting the $\mathrm{AR}$ axis in CRPC patients. Still, CRPC patients would probably benefit from the development of more specific AR-Vtargeting therapies.

\section{Role of intra-tumoural steroidogenesis in CRPC}

As described earlier, it is obvious that AR alterations in the epithelial tumours cells play a major role during development and growth of CRPC. In addition, intratumoural steroidogenesis may exist that potentiates AR activation in epithelial tumour cells but also has the possibility to affect AR-positive cells in the microenvironment, i.e. in stroma fibroblasts, smooth muscle cells, endothelial cells, osteoblasts and inflammatory cells, as reviewed in $(14,113)$. Numerous studies have reported persistent (or possibly returning) androgen levels in the prostate and in primary tumours after castration (114), and nuclear AR immunostaining can be seen not only in prostate epithelial but also in stroma cells after long-term castration (115). In both locally recurrent and metastatic CRPC, residual levels of testosterone and DHT have been reported at concentrations able to activate AR-mediated growth http://www.endocrineconnections.org DOI: 10.1530/EC-17-0118 (c) 2017 The authors Published by Bioscientifica Ltd
This work is licensed under a Creative Commons Attribution-NonCommercial-NoDerivatives 4.0 International License. 
in experimental PC models $(116,117)$. Also, adrenal androgens have been detected at biological relevant levels in PC after castration (118), and some studies suggest that circulating adrenal androgens contribute more than de novo synthesis to intra-tumoural steroid synthesis $(102,119,120)$. In CRPC bone metastases, we found significantly increased expression of some enzymes; AKR1C3 and SRD5A1, with the potential to convert the adrenal gland-derived steroids DHEA and androstenedione into testosterone and DHT, while levels of early steroidogenic enzymes converting cholesterol into DHEA and androstenedione (CYP11A1, CYP17A1, HSD3B2) were reduced compared to levels in prostate tissue (102). Notably, a large variation in androgen levels and in levels of steroid-converting enzymes has been reported between patients $(102,117)$. We found high AKR1C3 protein levels to be almost mutually exclusive from detectable protein levels of constitutively active AR-Vs in CRPC bone metastases (102), suggesting that AR-Vs may not be selected for in metastases that have the potential to synthesize sufficient amounts of androgens to activate the wild-type AR.

\section{Role of non-epithelial ARs in CRPC}

When the $\mathrm{AR}$ is discussed in relation to castration resistance, it is generally assumed that only epithelial ARs are of importance, but this could be an oversimplification. Especially, cases with intra-tumoural steroidogenesis may have the possibility to affect AR-positive cells in the microenvironment, as discussed above. In the normal prostate, castration-induced tissue involution is dependent on effects in the androgen-regulated stroma and vasculature $(14,113,121,122,123)$. Prostate tumours in patients are, for reasons largely unknown, characterized by a gradual loss of AR-positive cells in the tumour stroma, and this is in turn associated with a limited primary response to castration $(124,125,126)$. Castration resistance can thus be linked not only to increased AR activity in tumour epithelial cells but also to decreased AR signalling in the tumour microenvironment. If these two events are functionally coupled is not known, but nevertheless, they may contribute to a limited castration response in metastatic cells adopted to a less androgendependent microenvironment than tumour cells within the prostate.

Accordingly, the primary response to castration in AR-positive tumour epithelial cells has proven to be microenvironment dependent. In animals where AR-positive PC cells were injected both into the prostate and into the bone marrow, cells in the prostate responded considerably better to castration than those in the bone (127). This is apparently the case also in patients, as relapsed growth after castration and development of CRPC is far more common at metastatic sites (primarily in the bone marrow) than in the primary tumour. Cells in the bone marrow apparently influence tumour epithelial cells differently than those present in the prostate, and bone metastasis is thus the result of a complex reciprocal interaction between tumour cells and bone cells of different origin, as recently reviewed in (128). Metastatic cells in the bone environment are stimulated by survival factors released from activated osteoblasts and other cell types and by factors released from the bone matrix by resorbing osteoclasts. Cells of osteoblast and osteoclast origin have been shown to change AR co-regulator recruitment and activity (129). In turn, tumour cells feed this 'vicious cycle' through activation of osteoclastogenesis and subsequently the osteoblasts. Intratumoural steroidogenesis and local steroid secretion from metastatic cells probably affects AR-positive osteoblasts and may contribute to the sclerotic phenotype of PC bone metastases. Furthermore, the AR is present in various cell types of the immune system (130) and factors produced by macrophages $(131,132,133,134)$ and by lymphocytes (135) have been reported to influence AR signalling and the induction of castration resistance in PC cells.

Collectively, these studies suggest that even though the AR in tumour epithelial cells is of major importance in CRPC, the presence or loss of AR signalling in cells of the tumour/metastasis microenvironment also need to be considered. The importance of local steroidogenesis as well as of tumour cell interactions with androgen-responsive and non-androgen-responsive cells in the metastasis stroma for the establishment of bone metastasis and the development of CRPC need to be examined in more detail. With this, possibilities for novel therapies of CRPC targeting not only the tumour cells but also the metastasis stroma may arise.

\section{Conclusion and future directions}

Continuously accumulating evidence indicates that the $\mathrm{AR}$ is a main driver of CRPC. In addition to $A R$ amplification and overexpression, also $A R$ mutations, structural alterations and the enrichment of constitutively 
active AR-Vs appear to be of high clinical importance during development of CRPC and acquired resistance to ADT and AR antagonists (Fig. 1). Currently, clinical trials are ongoing where the predictive value of $A R$ mutations and AR-V expression is evaluated in relation to patient response/resistance to enzalutamide, abiraterone and other treatments for CRPC. Hopefully, those studies will demonstrate the value of measuring specific AR variants and mutations for therapeutic stratification. Furthermore, novel compound for targeting of constitutively active AR variants and/or receptors with activating mutations are under evaluation in clinical trials (Table 3 and www.clinicaltrials.gov). As recently reviewed $(85,136)$, preclinical studies have shown promising results for disrupting AR-V signalling by various strategies including targeting the AR NTD or DBD, reducing AR-V expression, promoting AR protein degradation, disrupting AR-V dimerization and chromatin binding, but further studies need to prove their clinical value. Alternatively, co-regulators to the AR and/or AR-Vs or their downstream gene products may be targeted. A novel AR antagonist, ODM-201, has been reported to overcome enzalutamide and apalutamide resistance and is currently in clinical trials $(137,138)$, so is also EPI-506, an AR antagonist that binds to the AR NTD and thus has the potential to inhibit not only full-length AR but also LBD-truncated variants (139, 140, $141,142)$. Response to EPI-506 will be evaluated in relation to AR-V7 CTC levels, in CRPC patients previously treated with enzalutamide and/or abiraterone (NCT02606123). Another highly interesting drug, galeterone, has been reported to promote degradation of the AR and AR-Vs and at the same time inhibit steroid synthesis and act as an AR antagonist $(143,144,145,146,147)$. Galeterone is compared to enzalutamide for treatment of AR-V7 positive CRPC patients (NCT02438007). Also niclosamide is in clinical trial for treatment of CRPC patients with AR-Vpositive tumors (NCT02532114), and has been shown to inhibit AR-V7 transcriptional activity and promote its proteasomal degradation to overcome enzalutamide and abiraterone resistance in preclinical models (148, 149, 150). Further compounds in clinical trials with suggested inhibitory effects on constitutively active AR variants include BET inhibitors, HSP90 inhibitors and antisense oligonucleotides (Table 3) $(78,101,151,152)$.

Novel treatments that will improve survival of men with metastatic PC may include not only more efficient drugs for treating CRPC, but also better strategies for primary treatment of M1 patients. Early chemotherapy

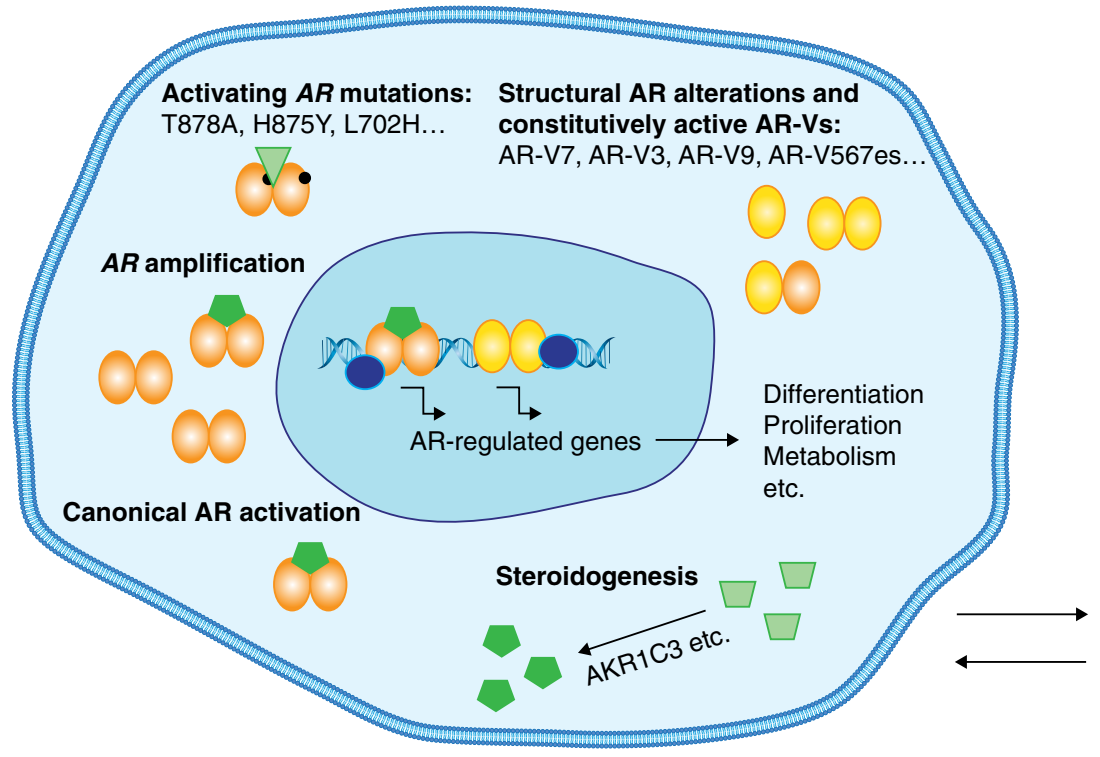

$A R$, wild-type

AR, point-mutated

AR-V, constitutively active

Co-regulator

Testosterone, Dihydrotestosterone

Adrenal androgen; DHEA or other precursor

Alternative ligand

Microenvironment
Fibroblasts / smooth muscle cells
Endothelial cells
Immune cells
Osteoblasts
Osteoclasts
Hematopoietic cells
etc.

Figure 1

Different molecular explanations behind androgen receptor (AR) activation in castration-resistant prostate cancer, illustrated by an epithelial cancer cell interacting with AR-positive and non-AR-positive cells in the microenvironment of a bone metastasis. AR amplification results in AR overexpression and possibilities for canonical AR signalling at low androgen concentration. Activating AR point mutations result in promiscuous receptors activated by weak androgens, other steroids and glucocorticoids as well as in turning AR antagonists into agonists. Structural AR alterations give enrichment of constitutively active AR variants (AR-Vs) that are able to dimerize, translocate into the nucleus and activate transcription of AR-regulated genes without the need for ligand binding. Tumour cells have the machinery for metabolizing weak androgens (i.e. adrenal-derived DHEA and androstenedione) into the more potent androgens testosterone and dihydrotestosterone. Different molecular mechanisms behind AR activation are seen in individual bone metastases, giving possibilities for therapy stratification in individual patients.

http://www.endocrineconnections.org DOI: 10.1530/EC-17-0118 (c) 2017 The authors Published by Bioscientifica Ltd

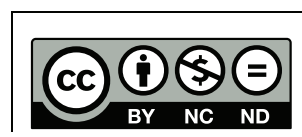

This work is licensed under a Creative Commons Attribution-NonCommercial-NoDerivatives 4.0 International License. 
Table 3 Novel compounds in clinical trials for treatment of CRPC with suggested mechanisms targeting the AR and/or its constitutively active variants. ${ }^{a}$

\begin{tabular}{|c|c|c|}
\hline Compound & Suggested mechanism & References $^{a}$ \\
\hline ODM-201 & $\begin{array}{l}\text { - AR antagonist, inhibiting nuclear translocation of AR including T878A, W742L, } \\
F 877 L \text { mutants }\end{array}$ & $(137,138)$ \\
\hline EPI-506 & - AR antagonist binding the AR NTD & $(139,140,141,142)$ \\
\hline Galeterone & $\begin{array}{ll}\text { - } & \text { Inhibits CYP17 } \\
\text { - } & \text { AR antagonist } \\
\text { - } & \text { Induces proteasomal degradation of AR and AR variants }\end{array}$ & $\begin{array}{l}(143,144,145,146, \\
147)\end{array}$ \\
\hline Niclosamide & $\begin{array}{l}\text { - Inhibits AR-V7 transcriptional activity } \\
\text { - Promotes AR-V7 proteasomal degradation }\end{array}$ & $(148,149,150)$ \\
\hline JQ1, OTX015 & $\begin{array}{l}\text { - Bromodomain and extra-terminal (BET) inhibitors disrupting interactions } \\
\text { between AR NTD, co-factors and chromatin, inhibiting transcriptional activity }\end{array}$ & $(152)$ \\
\hline Onalespib & - HSP90 inhibitor blocking AR-V7 mRNA splicing & $(101)$ \\
\hline EZN-4176, AZD-5312 & - Antisense oligonucleotides (ASOs) targeting expression of AR and AR variants & $(78)$ \\
\hline
\end{tabular}

${ }^{a}$ For clinical trials see www.clinicaltrials.gov.

with docetaxel given directly following ADT was recently shown to improve survival (153) and is now in clinical praxis. Now, interim results from the LATITUDE and STAMPEDE studies combining ADT with abiraterone for upfront treatment of metastasized PC show promising results with improved progression-free survival compared to standard ADT treatment $(154,155)$. Early abiraterone treatment of M1 patients may have the benefit of lowering residual steroid levels in metastases by inhibiting not only testicular and adrenal gland, but also intra-tumoural steroidogenesis and, consequently, lead to a more pronounced castration effect in tumour cells and also in AR-positive cells in the tumour microenvironment (Fig. 1).

Possible benefits of combining ADT with other therapies in early treatment of M1 patients are highly underexplored. Recent studies have proven the existence of prostate tumours of diverse molecular subtypes, based on somatic genetic aberrations or differential gene expression pattern $(22,156)$. You and coworkers performed meta-analysis of RNA profiles in primary prostate tumours and identified three PC subtypes, PCS1-3, with different phenotypic characteristics and prognosis (156). Pathway analysis of subtype-enriched genes revealed diverse cellular processes in the different subtypes, indicating possibilities for treatment stratification. Importantly, metastases can also be differentiated with respect to PCS1-3 related RNA profiles. By analysing subtype-enriched genes in biopsies from 69 bone metastases (patients), we found PCS2 to be the most frequent subtype (Thysell E, Ylitalo EB, Jernberg E, Bergh A \& Wikström P, unpublished observations). The PCS2 bone metastases (77\%) were characterized by AR activity and metabolic processes associated with differentiated prostate epithelial cells (i.e. lipid and sterol biosynthesis, PSA expression), while PCS1 cases showed cellular dedifferentiation and high proliferation and PCS3 appeared to be non-AR driven and more immunogenic (5; Thysell $\mathrm{E}$, Ylitalo EB, Jernberg E, Bergh A \& Wikström P, unpublished observations). $A R$ amplification and high AR-V expression were seen in both PCS1 and PCS2 bone metastases (21; Thysell E, Ylitalo EB, Jernberg E, Bergh A \& Wikström P, unpublished observations). Further studies are needed to explore if improved therapeutic results for PCS1 and PCS2 could be obtained by combining AR-directed therapies with treatment strategies selected based on tumour subtype. The PCS3 metastases will probably not respond to AR-directed therapies, but will need other therapeutic strategies.

\section{Declaration of interest}

The authors declare that there is no conflict of interest that could be perceived as prejudicing the impartiality of this review.

\section{Funding}

This work was supported by grants from the Swedish Research Council (K2013-64X-20407-04-3), the Swedish Cancer Society (CAN 2016/824 and CAN 2013/1324), Cancer Research Foundation in Northern Sweden and the county of Västerbotten.

\section{References}

1 Zhou CK, Check DP, Lortet-Tieulent J, Laversanne M, Jemal A, Ferlay J, Bray F, Cook MB \& Devesa SS. Prostate cancer incidence in 43 populations worldwide: an analysis of time trends overall and by age group. International Journal of Cancer 2016138 1388-1400. (doi:10.1002/ijc.29894)

2 Chen CD, Welsbie DS, Tran C, Baek SH, Chen R, Vessella R, Rosenfeld MG \& Sawyers CL. Molecular determinants of resistance to antiandrogen therapy. Nature Medicine 200410 33-39. (doi:10.1038/ nm972)

3 Holzbeierlein J, Lal P, LaTulippe E, Smith A, Satagopan J, Zhang L, Ryan C, Smith S, Scher H, Scardino P, et al. Gene expression analysis of human prostate carcinoma during hormonal therapy identifies androgen-responsive genes and mechanisms of therapy resistance. American Journal of Pathology 2004164 217-227. (doi:10.1016/S00029440(10)63112-4)

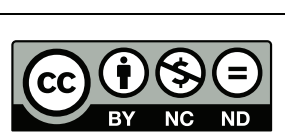

This work is licensed under a Creative Commons Attribution-NonCommercial-NoDerivatives 4.0 International License. 
4 Beltran H, Tomlins S, Aparicio A, Arora V, Rickman D, Ayala G, Huang J, True L, Gleave ME, Soule H, et al. Aggressive variants of castration-resistant prostate cancer. Clinical Cancer Research 201420 2846-2850. (doi:10.1158/1078-0432.CCR-13-3309)

5 Ylitalo EB, Thysell E, Jernberg E, Lundholm M, Crnalic S, Egevad L, Stattin P, Widmark A, Bergh A \& Wikström P. Subgroups of castration-resistant prostate cancer bone metastases defined through an inverse relationship between androgen receptor activity and immune response. European Urology 201771 776-787. (doi:10.1016/j. eururo.2016.07.033)

6 Nelson PS. Molecular states underlying androgen receptor activation: a framework for therapeutics targeting androgen signaling in prostate cancer. Journal of Clinical Oncology 201230 644-646. (doi:10.1200/ JCO.2011.39.1300)

7 Wadosky KM \& Koochekpour S. Molecular mechanisms underlying resistance to androgen deprivation therapy in prostate cancer. Oncotarget 20167 64447-64470. (doi:10.18632/oncotarget.10901)

8 Labrie F, Cusan L, Gomez J, Luu-The V, Candas B, Belanger A \& Labrie C. Major impact of hormonal therapy in localized prostate cancer-death can already be an exception. Journal of Steroid Biochemistry and Molecular Biology 200492 327-344. (doi:10.1016/j. jsbmb.2004.10.011)

9 Fizazi K, Scher HI, Molina A, Logothetis CJ, Chi KN, Jones RJ, Staffurth JN, North S, Vogelzang NJ, Saad F, et al. Abiraterone acetate for treatment of metastatic castration-resistant prostate cancer: final overall survival analysis of the COU-AA-301 randomised, doubleblind, placebo-controlled phase 3 study. Lancet Oncology 201213 983-992. (doi:10.1016/S1470-2045(12)70379-0)

10 Rathkopf DE, Antonarakis ES, Shore ND, Tutrone RF, Alumkal JJ, Ryan CJ, Saleh M, Hauke RJ, Bandekar R, Maneval EC, et al. Safety and antitumor activity of apalutamide (ARN-509) in metastatic castration-resistant prostate cancer with and without prior abiraterone acetate and prednisone. Clinical Cancer Research 201723 3544-3551.

11 Scher HI, Fizazi K, Saad F, Taplin ME, Sternberg CN, Miller K, de Wit R, Mulders P, Chi KN, Shore ND, et al. Increased survival with enzalutamide in prostate cancer after chemotherapy. New England Journal of Medicine 2012367 1187-1197. (doi:10.1056/ NEJMoa1207506)

12 Gelmann EP. Molecular biology of the androgen receptor. Journal of Clinical Oncology 200220 3001-3015. (doi:10.1200/JCO.2002.10.018)

13 Takayama K \& Inoue S. Transcriptional network of androgen receptor in prostate cancer progression. International Journal of Urology 2013 20 756-768. (doi:10.1111/iju.12146)

14 Hagglof C \& Bergh A. The stroma-a key regulator in prostate function and malignancy. Cancers 20124 531-548. (doi:10.3390/ cancers4020531)

15 Krongrad A, Wilson CM, Wilson JD, Allman DR \& McPhaul MJ. Androgen increases androgen receptor protein while decreasing receptor mRNA in LNCaP cells. Molecular and Cellular Endocrinology 199176 79-88. (doi:10.1016/0303-7207(91)90262-Q)

16 Cai C, He HH, Chen S, Coleman I, Wang H, Fang Z, Chen S, Nelson PS, Liu XS, Brown M, et al. Androgen receptor gene expression in prostate cancer is directly suppressed by the androgen receptor through recruitment of lysine-specific demethylase 1. Cancer Cell 201120 457-471. (doi:10.1016/j.ccr.2011.09.001)

17 Shan LX, Rodriguez MC \& Janne OA. Regulation of androgen receptor protein and mRNA concentrations by androgens in rat ventral prostate and seminal vesicles and in human hepatoma cells. Molecular Endocrinology 19904 1636-1646. (doi:10.1210/mend-411-1636)

18 Visakorpi T, Hyytinen E, Koivisto P, Tanner M, Keinanen R, Palmberg C, Palotie A, Tammela T, Isola J \& Kallioniemi OP. In vivo amplification of the androgen receptor gene and progression of human prostate cancer. Nature Genetics 19959 401-406. (doi:10.1038/ng0495-401)
19 Grasso CS, Wu YM, Robinson DR, Cao X, Dhanasekaran SM, Khan AP, Quist MJ, Jing X, Lonigro RJ, Brenner JC, et al. The mutational landscape of lethal castration-resistant prostate cancer. Nature 2012487 239-243. (doi:10.1038/nature11125)

20 Robinson D, Van Allen EM, Wu YM, Schultz N, Lonigro RJ, Mosquera JM, Montgomery B, Taplin ME, Pritchard CC, Attard G, et al. Integrative clinical genomics of advanced prostate cancer. Cell 2015161 1215-1228. (doi:10.1016/j.cell.2015.05.001)

21 Djusberg E, Jernberg E, Thysell E, Golovleva I, Lundberg P, Crnalic S, Widmark A, Bergh A, Brattsand M \& Wikström P. High levels of the AR-V7 splice variant and co-amplification of the Golgi protein coding YIPF6 in AR amplified prostate cancer bone metastases. Prostate $2017 \mathbf{7 7}$ 625-638. (doi:10.1002/pros.23307)

22 Cancer Genome Atlas Research N. The molecular taxonomy of primary prostate cancer. Cell. 2015163 1011-1025.

23 Linja MJ, Savinainen KJ, Saramaki OR, Tammela TL, Vessella RL \& Visakorpi T. Amplification and overexpression of androgen receptor gene in hormone-refractory prostate cancer. Cancer Research 200161 3550-3555.

24 Waltering KK, Helenius MA, Sahu B, Manni V, Linja MJ, Janne OA $\&$ Visakorpi T. Increased expression of androgen receptor sensitizes prostate cancer cells to low levels of androgens. Cancer Research 2009 69 8141-8149. (doi:10.1158/0008-5472.CAN-09-0919)

25 Azad AA, Volik SV, Wyatt AW, Haegert A, Le Bihan S, Bell RH, Anderson SA, McConeghy B, Shukin R, Bazov J, et al. Androgen receptor gene aberrations in circulating cell-free DNA: biomarkers of therapeutic resistance in castration-resistant prostate cancer. Clinical Cancer Research 201521 2315-2324. (doi:10.1158/1078-0432.CCR14-2666)

26 Romanel A, Gasi Tandefelt D, Conteduca V, Jayaram A, Casiraghi N, Wetterskog D, Salvi S, Amadori D, Zafeiriou Z, Rescigno P, et al. Plasma AR and abiraterone-resistant prostate cancer. Science Translational Medicine 20157 312re10. (doi:10.1126/scitranslmed. aac9511)

27 Taylor BS, Schultz N, Hieronymus H, Gopalan A, Xiao Y, Carver BS, Arora VK, Kaushik P, Cerami E, Reva B, et al. Integrative genomic profiling of human prostate cancer. Cancer Cell 201018 11-22. (doi:10.1016/j.ccr.2010.05.026)

28 Balk SP. Androgen receptor as a target in androgen-independent prostate cancer. Urology 200260 132-138. (doi:10.1016/S00904295(02)01593-5)

29 Steinkamp MP, O’Mahony OA, Brogley M, Rehman H, Lapensee EW, Dhanasekaran S, Hofer MD, Kuefer R, Chinnaiyan A, Rubin MA, et al. Treatment-dependent androgen receptor mutations in prostate cancer exploit multiple mechanisms to evade therapy. Cancer Research 200969 4434-4442. (doi:10.1158/0008-5472.CAN-08-3605)

30 Gottlieb B, Beitel LK, Nadarajah A, Paliouras M \& Trifiro M. The androgen receptor gene mutations database: 2012 update. Human Mutation 201233 887-894. (doi:10.1002/humu.22046)

31 Lorente D, Mateo J, Zafeiriou Z, Smith AD, Sandhu S, Ferraldeschi R \& de Bono JS. Switching and withdrawing hormonal agents for castration-resistant prostate cancer. Nature Reviews Urology 201512 37-47. (doi:10.1038/nrurol.2014.345)

32 Veldscholte J, Ris-Stalpers C, Kuiper GG, Jenster G, Berrevoets C, Claassen E, van Rooij HC, Trapman J, Brinkmann AO \& Mulder E. A mutation in the ligand binding domain of the androgen receptor of human LNCaP cells affects steroid binding characteristics and response to anti-androgens. Biochemical and Biophysical Research Communications 1990173 534-540. (doi:10.1016/S0006291X(05)80067-1)

33 Fenton MA, Shuster TD, Fertig AM, Taplin ME, Kolvenbag G, Bubley GJ \& Balk SP. Functional characterization of mutant androgen receptors from androgen-independent prostate cancer. Clinical Cancer Research 19973 1383-1388.

34 Taplin ME, Bubley GJ, Ko YJ, Small EJ, Upton M, Rajeshkumar B $\&$ Balk SP. Selection for androgen receptor mutations in prostate

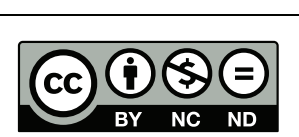

This work is licensed under a Creative Commons Attribution-NonCommercial-NoDerivatives 4.0 International License. 
cancers treated with androgen antagonist. Cancer Research 199959 2511-2515.

35 Taplin ME, Bubley GJ, Shuster TD, Frantz ME, Spooner AE, Ogata GK, Keer HN \& Balk SP. Mutation of the androgen-receptor gene in metastatic androgen-independent prostate cancer. New England Journal of Medicine 1995332 1393-1398. (doi:10.1056/ NEJM199505253322101)

36 Yoshida T, Kinoshita H, Segawa T, Nakamura E, Inoue T, Shimizu Y, Kamoto T \& Ogawa O. Antiandrogen bicalutamide promotes tumor growth in a novel androgen-dependent prostate cancer xenograft model derived from a bicalutamide-treated patient. Cancer Research 200565 9611-9616. (doi:10.1158/0008-5472.CAN-05-0817)

37 Watson PA, Arora VK \& Sawyers CL. Emerging mechanisms of resistance to androgen receptor inhibitors in prostate cancer. Nature Reviews Cancer 201515 701-711. (doi:10.1038/nrc4016)

38 Lallous N, Volik SV, Awrey S, Leblanc E, Tse R, Murillo J, Singh K, Azad AA, Wyatt AW, LeBihan S, et al. Functional analysis of androgen receptor mutations that confer anti-androgen resistance identified in circulating cell-free DNA from prostate cancer patients. Genome Biology 201617 10. (doi:10.1186/s13059-015-0864-1)

39 Taplin ME, Rajeshkumar B, Halabi S, Werner CP, Woda BA, Picus J, Stadler W, Hayes DF, Kantoff PW, Vogelzang NJ, et al. Androgen receptor mutations in androgen-independent prostate cancer: cancer and leukemia group B study 9663. Journal of Clinical Oncology 2003 21 2673-2678. (doi:10.1200/JCO.2003.11.102)

40 Steketee K, Timmerman L, Ziel-van der Made AC, Doesburg P, Brinkmann AO \& Trapman J. Broadened ligand responsiveness of androgen receptor mutants obtained by random amino acid substitution of H874 and mutation hot spot T877 in prostate cancer. International Journal of Cancer 2002100 309-317. (doi:10.1002/ ijc.10495)

41 Tan J, Sharief Y, Hamil KG, Gregory CW, Zang DY, Sar M, Gumerlock PH, deVere White RW, Pretlow TG, Harris SE, et al. Dehydroepiandrosterone activates mutant androgen receptors expressed in the androgen-dependent human prostate cancer xenograft CWR22 and LNCaP cells. Molecular Endocrinology 199711 450-459. (doi:10.1210/mend.11.4.9906)

42 Joseph JD, Lu N, Qian J, Sensintaffar J, Shao G, Brigham D, Moon M, Maneval EC, Chen I, Darimont B, et al. A clinically relevant androgen receptor mutation confers resistance to second-generation antiandrogens enzalutamide and ARN-509. Cancer Discovery 20133 1020-1029. (doi:10.1158/2159-8290.CD-13-0226)

43 Balbas MD, Evans MJ, Hosfield DJ, Wongvipat J, Arora VK, Watson PA, Chen Y, Greene GL, Shen Y \& Sawyers CL. Overcoming mutation-based resistance to antiandrogens with rational drug design. eLife 20132 e00499.

44 Korpal M, Korn JM, Gao X, Rakiec DP, Ruddy DA, Doshi S, Yuan J, Kovats SG, Kim S, Cooke VG, et al. An F876L mutation in androgen receptor confers genetic and phenotypic resistance to MDV3100 (enzalutamide). Cancer Discovery 20133 1030-1043. (doi:10.1158/2159-8290.CD-13-0142)

45 Arora VK, Schenkein E, Murali R, Subudhi SK, Wongvipat J, Balbas MD, Shah N, Cai L, Efstathiou E, Logothetis C, et al. Glucocorticoid receptor confers resistance to antiandrogens by bypassing androgen receptor blockade. Cell 2013155 1309-1322. (doi:10.1016/j.cell.2013.11.012)

46 Isikbay M, Otto K, Kregel S, Kach J, Cai Y, Vander Griend DJ, Conzen SD \& Szmulewitz RZ. Glucocorticoid receptor activity contributes to resistance to androgen-targeted therapy in prostate cancer. Hormones and Cancer 20145 72-89.

47 Chen EJ, Sowalsky AG, Gao S, Cai C, Voznesensky O, Schaefer R, Loda M, True LD, Ye H, Troncoso P, et al. Abiraterone treatment in castration-resistant prostate cancer selects for progesterone responsive mutant androgen receptors. Clinical Cancer Research 2015 21 1273-1280. (doi:10.1158/1078-0432.CCR-14-1220)
48 Steinestel J, Luedeke M, Arndt A, Schnoeller TJ, Lennerz JK, Wurm C, Maier C, Cronauer MV, Steinestel K \& Schrader AJ Detecting predictive androgen receptor modifications in circulating prostate cancer cells. Oncotarget 2015 pii: 3925. (doi:10.18632/ oncotarget.3925)

49 Wyatt AW, Azad AA, Volik SV, Annala M, Beja K, McConeghy B, Haegert A, Warner EW, Mo F, Brahmbhatt S, et al. Genomic alterations in cell-free DNA and enzalutamide resistance in castration-resistant prostate cancer. JAMA Oncology 20162 1598-1606. (doi:10.1001/jamaoncol.2016.0494)

50 Carreira S, Romanel A, Goodall J, Grist E, Ferraldeschi R, Miranda S, Prandi D, Lorente D, Frenel JS, Pezaro C, et al. Tumor clone dynamics in lethal prostate cancer. Science Translational Medicine 20146 254ra125. (doi:10.1126/scitranslmed.3009448)

51 Bova GS, Kallio HM, Annala M, Kivinummi K, Hognas G, Hayrynen S, Rantapero T, Kivinen V, Isaacs WB, Tolonen T, et al. Integrated clinical, whole-genome, and transcriptome analysis of multisampled lethal metastatic prostate cancer. Cold Spring Harbor Molecular Case Studies 20162 a000752. (doi:10.1101/mcs.a000752)

52 Zhao XY, Malloy PJ, Krishnan AV, Swami S, Navone NM, Peehl DM \& Feldman D. Glucocorticoids can promote androgen-independent growth of prostate cancer cells through a mutated androgen receptor. Nature Medicine 20006 703-706. (doi:10.1038/76287)

53 Li Y, Alsagabi M, Fan D, Bova GS, Tewfik AH \& Dehm SM. Intragenic rearrangement and altered RNA splicing of the androgen receptor in a cell-based model of prostate cancer progression. Cancer Research 201171 2108-2117. (doi:10.1158/0008-5472.CAN-10-1998)

54 Li Y, Hwang TH, Oseth LA, Hauge A, Vessella RL, Schmechel SC, Betsy H, Beckman KB, Silverstein KA \& Dehm SM. AR intragenic deletions linked to androgen receptor splice variant expression and activity in models of prostate cancer progression. Oncogene 201231 4759-4767. (doi:10.1038/onc.2011.637)

55 Nyquist MD, Li Y, Hwang TH, Manlove LS, Vessella RL, Silverstein KA, Voytas DF \& Dehm SM. TALEN-engineered AR gene rearrangements reveal endocrine uncoupling of androgen receptor in prostate cancer. PNAS 2013110 17492-17497. (doi:10.1073/ pnas.1308587110)

56 Henzler C, Li Y, Yang R, McBride T, Ho Y, Sprenger C, Liu G, Coleman I, Lakely B, Li R, et al. Truncation and constitutive activation of the androgen receptor by diverse genomic rearrangements in prostate cancer. Nature Communications 20167 13668. (doi:10.1038/ncomms13668)

57 De Laere B, van Dam PJ, Whitington T, Mayrhofer M, Diaz EH, Vanden Eynden G, Vandebroek J, Del-Favero J, Van Laere S, Dirix L, et al. Comprehensive profiling of the androgen receptor in liquid biopsies from castration-resistant prostate cancer reveals novel intra-AR structural variation and splice variant expression patterns. European Urology 201772 192-200.

58 Tepper CG, Boucher DL, Ryan PE, Ma AH, Xia L, Lee LF, Pretlow TG \& Kung HJ. Characterization of a novel androgen receptor mutation in a relapsed CWR22 prostate cancer xenograft and cell line. Cancer Research 200262 6606-6614.

59 Dehm SM, Schmidt LJ, Heemers HV, Vessella RL \& Tindall DJ. Splicing of a novel androgen receptor exon generates a constitutively active androgen receptor that mediates prostate cancer therapy resistance. Cancer Research 200868 5469-5477. (doi:10.1158/00085472.CAN-08-0594)

60 Dehm SM \& Tindall DJ. Alternatively spliced androgen receptor variants. Endocrine-Related Cancer 201118 R183-R196. (doi:10.1530/ ERC-11-0141)

$61 \mathrm{Lu}$ C \& Luo J. Decoding the androgen receptor splice variants. Translational Andrology and Urology 20132 178-186.

62 Guo Z, Yang X, Sun F, Jiang R, Linn DE, Chen H, Chen H, Kong X, Melamed J, Tepper CG, et al. A novel androgen receptor splice variant is up-regulated during prostate cancer progression and http://www.endocrineconnections.org

DOI: 10.1530/EC-17-0118
() 2017 The authors Published by Bioscientifica Ltd
This work is licensed under a Creative Commons Attribution-NonCommercial-NoDerivatives 4.0 International License. 
promotes androgen depletion-resistant growth. Cancer Research 2009 69 2305-2313. (doi:10.1158/0008-5472.CAN-08-3795)

$63 \mathrm{Hu}$ R, Dunn TA, Wei S, Isharwal S, Veltri RW, Humphreys E, Han M, Partin AW, Vessella RL, Isaacs WB, et al. Ligand-independent androgen receptor variants derived from splicing of cryptic exons signify hormone-refractory prostate cancer. Cancer Research 200969 16-22. (doi:10.1158/0008-5472.CAN-08-2764)

64 Sun S, Sprenger CC, Vessella RL, Haugk K, Soriano K, Mostaghel EA, Page ST, Coleman IM, Nguyen HM, Sun H, et al. Castration resistance in human prostate cancer is conferred by a frequently occurring androgen receptor splice variant. Journal of Clinical Investigation 2010 120 2715-2730. (doi:10.1172/JCI41824)

65 Hornberg E, Ylitalo EB, Crnalic S, Antti H, Stattin P, Widmark A, Bergh A \& Wikström P. Expression of androgen receptor splice variants in prostate cancer bone metastases is associated with castration-resistance and short survival. PLOS ONE 20116 e19059. (doi:10.1371/journal.pone.0019059)

66 Qu Y, Dai B, Ye D, Kong Y, Chang K, Jia Z, Yang X, Zhang H, Zhu Y \& Shi G. Constitutively active AR-V7 plays an essential role in the development and progression of castration-resistant prostate cancer Scientific Reports 20155 7654. (doi:10.1038/srep07654)

67 Welti J, Rodrigues DN, Sharp A, Sun S, Lorente D, Riisnaes R, Figueiredo I, Zafeiriou Z, Rescigno P, de Bono JS, et al. Analytical validation and clinical qualification of a new immunohistochemical assay for androgen receptor splice variant-7 protein expression in metastatic castration-resistant prostate cancer. European Urology 2016 70 599-608. (doi:10.1016/j.eururo.2016.03.049)

$68 \mathrm{Hu}$ R, Isaacs WB \& Luo J. A snapshot of the expression signature of androgen receptor splicing variants and their distinctive transcriptional activities. Prostate 201171 1656-1667. (doi:10.1002/ pros.21382)

69 Kohli M, Ho Y, Hillman DW, Van Etten JL, Henzler C, Yang R, Sperger JM, Li Y, Tseng E, Hon T, et al. Androgen receptor variant AR-V9 is co-expressed with AR-V7 in prostate cancer metastases and predicts abiraterone resistance. Clinical Cancer Research 201723 4704-4715.

70 Chan SC, Li Y \& Dehm SM. Androgen receptor splice variants activate androgen receptor target genes and support aberrant prostate cancer cell growth independent of canonical androgen receptor nuclear localization signal. Journal of Biological Chemistry 2012287 19736-19749. (doi:10.1074/jbc.M112.352930)

71 Watson PA, Chen YF, Balbas MD, Wongvipat J, Socci ND, Viale A, Kim K \& Sawyers CL. Constitutively active androgen receptor splice variants expressed in castration-resistant prostate cancer require full-length androgen receptor. PNAS 2010107 16759-16765. (doi:10.1073/pnas.1012443107)

72 Mostaghel EA, Marck BT, Plymate SR, Vessella RL, Balk S, Matsumoto AM, Nelson PS \& Montgomery RB. Resistance to CYP17A1 inhibition with abiraterone in castration-resistant prostate cancer: induction of steroidogenesis and androgen receptor splice variants. Clinical Cancer Research 201117 5913-5925. (doi:10.1158/1078-0432.CCR-11-0728)

73 Li Y, Chan SC, Brand LJ, Hwang TH, Silverstein KA \& Dehm SM. Androgen receptor splice variants mediate enzalutamide resistance in castration-resistant prostate cancer cell lines. Cancer Research 201373 483-489. (doi:10.1158/0008-5472.CAN-12-3630)

74 Nadiminty N, Tummala R, Liu C, Yang J, Lou W, Evans CP \& Gao AC. NF-kappaB2/p52 induces resistance to enzalutamide in prostate cancer: role of androgen receptor and its variants. Molecular Cancer Therapeutics 201312 1629-1637. (doi:10.1158/1535-7163.MCT -13-0027)

75 Cao B, Qi Y, Zhang G, Xu D, Zhan Y, Alvarez X, Guo Z, Fu X, Plymate SR, Sartor O, et al. Androgen receptor splice variants activating the full-length receptor in mediating resistance to androgen-directed therapy. Oncotarget 20145 1646-1656. (doi:10.18632/oncotarget.1802)
76 Knuuttila M, Yatkin E, Kallio J, Savolainen S, Laajala TD, Aittokallio T, Oksala R, Häkkinen M, Keski-Rahkonen P, Auriola S, et al. Castration induces up-regulation of intratumoral androgen biosynthesis and androgen receptor expression in an orthotopic VCaP human prostate cancer xenograft model. American Journal of Pathology 2014184 2163-2173. (doi:10.1016/j.ajpath.2014.04.010)

77 Yu Z, Chen S, Sowalsky AG, Voznesensky OS, Mostaghel EA, Nelson PS, Cai C \& Balk SP. Rapid induction of androgen receptor splice variants by androgen deprivation in prostate cancer. Clinical Cancer Research 201420 1590-1600. (doi:10.1158/1078-0432.CCR13-1863)

78 Yamamoto Y, Loriot Y, Beraldi E, Zhang F, Wyatt AW, Al Nakouzi N, Mo F, Zhou T, Kim Y, Monia BP, et al. Generation 2.5 antisense oligonucleotides targeting the androgen receptor and its splice variants suppress enzalutamide-resistant prostate cancer cell growth. Clinical Cancer Research 201521 1675-1687. (doi:10.1158/1078-0432. CCR-14-1108)

79 Yang L, Lin C, Jin C, Yang JC, Tanasa B, Li W, Merkurjev D, Ohgi KA, Meng D, Zhang J, et al. lncRNA-dependent mechanisms of androgenreceptor-regulated gene activation programs. Nature $2013 \mathbf{5 0 0}$ 598-602. (doi:10.1038/nature12451)

80 Xu D, Zhan Y, Qi Y, Cao B, Bai S, Xu W, Gambhir SS, Lee P, Sartor O, Flemington EK, et al. Androgen receptor splice variants dimerize to transactivate target genes. Cancer Research 201575 3663-3671. (doi:10.1158/0008-5472.CAN-15-0381)

$81 \mathrm{Lu}$ J, Lonergan PE, Nacusi LP, Wang L, Schmidt LJ, Sun Z, Van der Steen T, Boorjian SA, Kosari F, Vasmatzis G, et al. The cistrome and gene signature of androgen receptor splice variants in castration resistant prostate cancer cells. Journal of Urology 2015193 690-698. (doi:10.1016/j.juro.2014.08.043)

$82 \mathrm{Hu}$ R, Lu C, Mostaghel EA, Yegnasubramanian S, Gurel M, Tannahill C, Edwards J, Isaacs WB, Nelson PS, Bluemn E, et al. Distinct transcriptional programs mediated by the ligand-dependent full-length androgen receptor and its splice variants in castrationresistant prostate cancer. Cancer Research 201272 3457-3462. (doi:10.1158/0008-5472.CAN-11-3892)

83 Krause WC, Shafi AA, Nakka M \& Weigel NL. Androgen receptor and its splice variant, AR-V7, differentially regulate FOXA1 sensitive genes in LNCaP prostate cancer cells. International Journal of Biochemistry and Cell Biology 201454 49-59.

84 Chan SC, Selth LA, Li Y, Nyquist MD, Miao L, Bradner JE, Raj GV, Tilley WD \& Dehm SM. Targeting chromatin binding regulation of constitutively active AR variants to overcome prostate cancer resistance to endocrine-based therapies. Nucleic Acids Research 2015 43 5880-5897. (doi:10.1093/nar/gkv262)

85 Cao S, Zhan Y \& Dong Y. Emerging data on androgen receptor splice variants in prostate cancer. Endocrine-Related Cancer 201623 T199-T210. (doi:10.1530/ERC-16-0298)

86 Wang Q, Li W, Zhang Y, Yuan X, Xu K, Yu J, Chen Z, Beroukhim R, Wang $\mathrm{H}$, Lupien $\mathrm{M}$, et al. Androgen receptor regulates a distinct transcription program in androgen-independent prostate cancer. Cell 2009138 245-256. (doi:10.1016/j.cell.2009.04.056)

87 Chen Z, Zhang C, Wu D, Chen H, Rorick A, Zhang X \& Wang Q. Phospho-MED1-enhanced UBE2C locus looping drives castrationresistant prostate cancer growth. EMBO Journal 201130 2405-2419. (doi:10.1038/emboj.2011.154)

88 Liu G, Sprenger C, Wu PJ, Sun S, Uo T, Haugk K \& Plymate S. MED1 mediates androgen receptor splice variant induced gene expression in the absence of ligand. Oncotarget 20156 288-304. (doi:10.18632/ oncotarget.2672)

89 He B, Lanz RB, Fiskus W, Geng C, Yi P, Hartig SM, Rajapakshe K, Shou J, Wei L, Shah SS, et al. GATA2 facilitates steroid receptor coactivator recruitment to the androgen receptor complex. PNAS 2014111 18261-18266. (doi:10.1073/pnas.1421415111)

90 Jones D, Wade M, Nakjang S, Chaytor L, Grey J, Robson CN \& Gaughan L. FOXA1 regulates androgen receptor variant activity

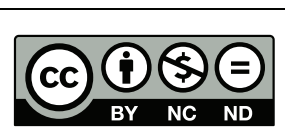

This work is licensed under a Creative Commons Attribution-NonCommercial-NoDerivatives 4.0 International License. 
in models of castrate-resistant prostate cancer. Oncotarget 20156 29782-29794. (doi:10.18632/oncotarget.4927)

91 Wang Q, Li W, Liu XS, Carroll JS, Janne OA, Keeton EK, Chinnaiyan AM, Pienta KJ \& Brown M. A hierarchical network of transcription factors governs androgen receptor-dependent prostate cancer growth. Molecular Cell 200727 380-392. (doi:10.1016/j. molcel.2007.05.041)

92 Bohm M, Locke WJ, Sutherland RL, Kench JG \& Henshall SM. A role for GATA-2 in transition to an aggressive phenotype in prostate cancer through modulation of key androgen-regulated genes. Oncogene 200928 3847-3856. (doi:10.1038/onc.2009.243)

93 Wu D, Sunkel B, Chen Z, Liu X, Ye Z, Li Q, Grenade C, Ke J, Zhang C, Chen $\mathrm{H}$, et al. Three-tiered role of the pioneer factor GATA2 in promoting androgen-dependent gene expression in prostate cancer. Nucleic Acids Research 201442 3607-3622. (doi:10.1093/nar/gkt1382)

94 Ostling P, Leivonen SK, Aakula A, Kohonen P, Makela R, Hagman Z, Edsjö A, Kangaspeska S, Edgren H, Nicorici D, et al. Systematic analysis of microRNAs targeting the androgen receptor in prostate cancer cells. Cancer Research 201171 1956-1967. (doi:10.1158/00085472.CAN-10-2421)

95 Yang Y, Jia D, Kim H, Abd Elmageed ZY, Datta A, Davis R, Srivastav S, Moroz K, Crawford BE, Moparty K, et al. Dysregulation of miR212 promotes castration resistance through hnRNPH1-mediated regulation of AR and AR-V7: implications for racial disparity of prostate cancer. Clinical Cancer Research 201622 1744-1756. (doi:10.1158/1078-0432.CCR-15-1606)

96 Auboeuf D, Honig A, Berget SM \& O'Malley BW. Coordinate regulation of transcription and splicing by steroid receptor coregulators. Science 2002298 416-419. (doi:10.1126/ science.1073734)

97 Nogues G, Kadener S, Cramer P, Bentley D \& Kornblihtt AR. Transcriptional activators differ in their abilities to control alternative splicing. Journal of Biological Chemistry 2002277 43110-43114. (doi:10.1074/jbc.M208418200)

98 Kornblihtt AR. Coupling transcription and alternative splicing. Advances in Experimental Medicine and Biology 2007623 175-189.

99 Liu LL, Xie N, Sun S, Plymate S, Mostaghel E \& Dong X. Mechanisms of the androgen receptor splicing in prostate cancer cells. Oncogene 201433 3140-3150. (doi:10.1038/onc.2013.284)

100 Nadiminty N, Tummala R, Liu C, Lou W, Evans CP \& Gao AC. NF-kappaB2/p52:c-Myc:hnRNPA1 pathway regulates expression of androgen receptor splice variants and enzalutamide sensitivity in prostate cancer. Molecular Cancer Therapeutics 201514 1884-1895. (doi:10.1158/1535-7163.MCT-14-1057)

101 Ferraldeschi R, Welti J, Powers MV, Yuan W, Smyth T, Seed G, Riisnaes R, Hedayat S, Wang H, Crespo M, et al. Second-generation HSP90 inhibitor onalespib blocks mRNA splicing of androgen receptor variant 7 in prostate cancer cells. Cancer Research 201676 2731-2742. (doi:10.1158/0008-5472.CAN-15-2186)

102 Jernberg E, Thysell E, Bovinder Ylitalo E, Rudolfsson S, Crnalic S, Widmark A, Bergh A \& Wikström P. Characterization of prostate cancer bone metastases according to expression levels of steroidogenic enzymes and androgen receptor splice variants. PLoS ONE 20138 e77407. (doi:10.1371/journal.pone.0077407)

103 Efstathiou E, Titus M, Wen S, Hoang A, Karlou M, Ashe R, Tu SM, Aparicio A, Troncoso P, Mohler J, et al. Molecular characterization of enzalutamide-treated bone metastatic castration-resistant prostate cancer. European Urology 201567 53-60. (doi:10.1016/j eururo.2014.05.005)

104 Antonarakis ES, Lu C, Wang H, Luber B, Nakazawa M, Roeser JC, Chen Y, Mohammad TA, Chen Y \& Fedor HL. AR-V7 and resistance to enzalutamide and abiraterone in prostate cancer. New England Journal of Medicine 2014371 1028-1038. (doi:10.1056/ NEJMoa1315815)
105 Antonarakis ES, Lu C, Luber B, Wang H, Chen Y, Zhu Y, Silberstein JL, Taylor MN, Maughan BL, Denmeade SR, et al. Clinical significance of androgen receptor splice variant-7 mRNA detection in circulating tumor cells of men with metastatic castration-resistant prostate cancer treated with first- and second-line abiraterone and enzalutamide. Journal of Clinical Oncology 201735 2149-2156.

106 Liu X, Ledet E, Li D, Dotiwala A, Steinberger A, Feibus A, Li J, Qi Y, Silberstein J, Lee B, et al. A whole blood assay for AR-V7 and ARv567es in patients with prostate cancer. Journal of Urology 2016 196 1758-1763. (doi:10.1016/j.juro.2016.06.095)

107 Qu F, Xie W, Nakabayashi M, Zhang H, Jeong SH, Wang X, Komura K, Sweeney CJ, Sartor O, Mary Lee G-S, et al. Association of AR-V7 and prostate-specific antigen RNA levels in blood with efficacy of abiraterone acetate and enzalutamide treatment in men with prostate cancer. Clinical Cancer Research 201723 726-734. (doi:10.1158/1078-0432.CCR-16-1070)

108 Zhang G, Liu X, Li J, Ledet E, Alvarez X, Qi Y, Fu X, Sartor O, Dong Y \& Zhang $\mathrm{H}$. Androgen receptor splice variants circumvent AR blockade by microtubule-targeting agents. Oncotarget 20156 23358-23371. (doi:10.18632/oncotarget.4396)

109 Thadani-Mulero M, Portella L, Sun S, Sung M, Matov A, Vessella RL, Corey E, Nanus DM, Plymate SR \& Giannakakou P. Androgen receptor splice variants determine taxane sensitivity in prostate cancer. Cancer Research 201474 2270-2282. (doi:10.1158/0008-5472.CAN-13-2876)

110 Antonarakis ES, Lu C, Luber B, Wang H, Chen Y, Nakazawa M, Nadal R, Paller CJ, Denmeade SR, Carducci MA, et al. Androgen receptor splice variant 7 and efficacy of taxane chemotherapy in patients with metastatic castration-resistant prostate cancer. JAMA Oncology 20151 582-591. (doi:10.1001/jamaoncol.2015.1341)

111 Onstenk W, Sieuwerts AM, Kraan J, Van M, Nieuweboer AJ, Mathijssen RH, Hamberg P, Meulenbeld HJ, De Laere B, Dirix LY, et al. Efficacy of cabazitaxel in castration-resistant prostate cancer is independent of the presence of AR-V7 in circulating tumor cells. European Urology 201568 939-945. (doi:10.1016/j. eururo.2015.07.007)

112 Scher HI, Lu D, Schreiber NA, Louw J, Graf RP, Vargas HA, Johnson A, Jendrisak A, Bambury R, Danila D, et al. Association of AR-V7 on circulating tumor cells as a treatment-specific biomarker with outcomes and survival in castration-resistant prostate cancer. JAMA Oncology 20162 1441-1449. (doi:10.1001/jamaoncol.2016.1828)

113 Leach DA \& Buchanan G. Stromal androgen receptor in prostate cancer development and progression. Cancers 2017910.

114 Mostaghel EA. Beyond T and DHT - novel steroid derivatives capable of wild type androgen receptor activation. International Journal of Biological Sciences 201410 602-613. (doi:10.7150/ijbs.8844)

115 Wikstrom P, Ohlson N, Stattin P \& Bergh A. Nuclear androgen receptors recur in the epithelial and stromal compartments of malignant and non-malignant human prostate tissue several months after castration therapy. Prostate 200767 1277-1284. (doi:10.1002/ pros.20569)

116 Mohler JL, Gregory CW, Ford OH 3rd, Kim D, Weaver CM, Petrusz P, Wilson EM \& French FS. The androgen axis in recurrent prostate cancer. Clinical Cancer Research 200410 440-448. (doi:10.1158/10780432.CCR-1146-03)

117 Montgomery RB, Mostaghel EA, Vessella R, Hess DL, Kalhorn TF, Higano CS, True LD \& Nelson PS. Maintenance of intratumoral androgens in metastatic prostate cancer: a mechanism for castrationresistant tumor growth. Cancer Research 200868 4447-4454. (doi:10.1158/0008-5472.CAN-08-0249)

118 Mizokami A, Koh E, Fujita H, Maeda Y, Egawa M, Koshida K, Honma S, Keller ET \& Namiki M. The adrenal androgen androstenediol is present in prostate cancer tissue after androgen deprivation therapy and activates mutated androgen receptor. Cancer Research 200464 765-771. (doi:10.1158/0008-5472.CAN-03-0130) http://www.endocrineconnections.org DOI: 10.1530/EC-17-0118
() 2017 The authors Published by Bioscientifica Ltd
This work is licensed under a Creative Commons Attribution-NonCommercial-NoDerivatives 4.0 International License. 
119 Hofland J, van Weerden WM, Dits NF, Steenbergen J, van Leenders GJ, Jenster G, Schröder FH \& de Jong FH. Evidence of limited contributions for intratumoral steroidogenesis in prostate cancer. Cancer Research 201070 1256-1264. (doi:10.1158/0008-5472. CAN-09-2092)

120 Kumagai J, Hofland J, Erkens-Schulze S, Dits NF, Steenbergen J, Jenster G, Homma Y, de Jong FH \& van Weerden WM. Intratumoral conversion of adrenal androgen precursors drives androgen receptoractivated cell growth in prostate cancer more potently than de novo steroidogenesis. Prostate 201373 1636-1650.

121 Kurita T, Wang YZ, Donjacour AA, Zhao C, Lydon JP, O’Malley BW, Isaacs JT, Dahiya R \& Cunha GR. Paracrine regulation of apoptosis by steroid hormones in the male and female reproductive system. Cell Death and Differentiation 20018 192-200. (doi:10.1038/ sj.cdd.4400797)

122 Lissbrant IF, Lissbrant E, Damber JE \& Bergh A. Blood vessels are regulators of growth, diagnostic markers and therapeutic targets in prostate cancer. Scandinavian Journal of Urology and Nephrology 2001 35 437-452. (doi:10.1080/003655901753367532)

123 Placencio VR, Sharif-Afshar AR, Li X, Huang H, Uwamariya C, Neilson EG, Shen MM, Matusik RJ, Hayward SW \& Bhowmick NA. Stromal transforming growth factor-beta signaling mediates prostatic response to androgen ablation by paracrine Wnt activity. Cancer Research 200868 4709-4718. (doi:10.1158/0008-5472.CAN-07-6289)

124 Ohlson N, Bergh A, Stattin P \& Wikstrom P. Castration-induced epithelial cell death in human prostate tissue is related to locally reduced IGF-1 levels. Prostate 200767 32-40. (doi:10.1002/ pros.20480)

125 Wikstrom P, Marusic J, Stattin P \& Bergh A. Low stroma androgen receptor level in normal and tumor prostate tissue is related to poor outcome in prostate cancer patients. Prostate 200969 799-809. (doi:10.1002/pros.20927)

126 Wu JP, Huang WB, Zhou H, Xu LW, Zhao JH, Zhu JG, Su JH \& Sun HB. Intensity of stromal changes is associated with tumor relapse in clinically advanced prostate cancer after castration therapy. Asian Journal of Andrology 201416 710-714. (doi:10.4103/1008-682X.129131)

127 Bergstrom SH, Rudolfsson SH \& Bergh A. Rat prostate tumor cells progress in the bone microenvironment to a highly aggressive phenotype. Neoplasia 201618 152-161. (doi:10.1016/j. neo.2016.01.007)

128 Olechnowicz SW \& Edwards CM. Contributions of the host microenvironment to cancer-induced bone disease. Cancer Research 201474 1625-1631. (doi:10.1158/0008-5472.CAN-13-2645)

129 Villagran MA, Gutierrez-Castro FA, Pantoja DF, Alarcon JC, Farina MA, Amigo RF, Muñoz-Godoy NA, Pinilla MG, Peña EA, Gonzalez-Chavarria I, et al. Bone stroma-derived cells change coregulators recruitment to androgen receptor and decrease cell proliferation in androgen-sensitive and castration-resistant prostate cancer cells. Biochemical and Biophysical Research Communications 2015467 1039-1045. (doi:10.1016/j.bbrc.2015.10.009)

130 Trigunaite A, Dimo J \& Jorgensen TN. Suppressive effects of androgens on the immune system. Cellular Immunology 2015294 87-94. (doi:10.1016/j.cellimm.2015.02.004)

131 Zhu P, Baek SH, Bourk EM, Ohgi KA, Garcia-Bassets I, Sanjo H, Akira S, Kotol PF, Glass CK, Rosenfeld MG, et al. Macrophage/cancer cell interactions mediate hormone resistance by a nuclear receptor derepression pathway. Cell 2006124 615-629. (doi:10.1016/j. cell.2005.12.032)

132 Lee GT, Jung YS, Ha YS, Kim JH, Kim WJ \& Kim IY. Bone morphogenetic protein- 6 induces castration resistance in prostate cancer cells through tumor infiltrating macrophages. Cancer Science 2013104 1027-1032. (doi:10.1111/cas.12206)

133 Nonomura N, Takayama H, Nakayama M, Nakai Y, Kawashima A, Mukai M, Nagahara A, Aozasa K \& Tsujimura A. Infiltration of tumour-associated macrophages in prostate biopsy specimens is

http://www.endocrineconnections.org DOI: 10.1530/EC-17-0118 (c) 2017 The authors Published by Bioscientifica Ltd predictive of disease progression after hormonal therapy for prostate cancer. BJU International 2011107 1918-1922. (doi:10.1111/j.1464410X.2010.09804.x)

134 Staverosky JA, Zhu XH, Ha S \& Logan SK. Anti-androgen resistance in prostate cancer cells chronically induced by interleukin-1beta. American Journal of Clinical and Experimental Urology 20131 53-65. (doi:10.11648/j.ajcem.20130103.13)

135 Ammirante M, Luo JL, Grivennikov S, Nedospasov S \& Karin M. B-cell-derived lymphotoxin promotes castration-resistant prostate cancer. Nature 2010464 302-305. (doi:10.1038/nature08782)

136 Coutinho I, Day TK, Tilley WD \& Selth LA. Androgen receptor signaling in castration-resistant prostate cancer: a lesson in persistence. Endocrine-Related Cancer 201623 T179-T197. (doi:10.1530/ERC-16-0422)

137 Fizazi K, Massard C, Bono P, Jones R, Kataja V, James N, Garcia JA, Protheroe A, Tammela TL, Elliott T, et al. Activity and safety of ODM-201 in patients with progressive metastatic castration-resistant prostate cancer (ARADES): an open-label phase 1 dose-escalation and randomised phase 2 dose expansion trial. Lancet Oncology 201415 975-985. (doi:10.1016/S1470-2045(14)70240-2)

138 Moilanen AM, Riikonen R, Oksala R, Ravanti L, Aho E, Wohlfahrt G, Nykänen PS, Törmäkangas OP, Palvimo JJ \& Kallio PJ. Discovery of ODM-201, a new-generation androgen receptor inhibitor targeting resistance mechanisms to androgen signaling-directed prostate cancer therapies. Scientific Reports 20155 12007. (doi:10.1038/ srep12007)

139 Antonarakis ES, Chandhasin C, Osbourne E, Luo J, Sadar MD $\&$ Perabo F. Targeting the N-terminal domain of the androgen receptor: a new approach for the treatment of advanced prostate cancer. Oncologist 201621 1427-1435. (doi:10.1634/ theoncologist.2016-0161)

140 Andersen RJ, Mawji NR, Wang J, Wang G, Haile S, Myung JK, Watt K, Tam T, Yang YC, Bañuelos CA, et al. Regression of castrate-recurrent prostate cancer by a small-molecule inhibitor of the amino-terminus domain of the androgen receptor. Cancer Cell 201017 535-546. (doi:10.1016/j.ccr.2010.04.027)

141 Myung JK, Banuelos CA, Fernandez JG, Mawji NR, Wang J, Tien AH, Yang YC, Tavakoli I, Haile S, Watt K, et al. An androgen receptor $\mathrm{N}$-terminal domain antagonist for treating prostate cancer. Journal of Clinical Investigation 2013123 2948-2960. (doi:10.1172/JCI66398)

142 Sadar MD. Small molecule inhibitors targeting the 'achilles' heel' of androgen receptor activity. Cancer Research 201171 1208-1213. (doi:10.1158/0008-5472.CAN_10-3398)

143 Kwegyir-Afful AK, Ramalingam S, Purushottamachar P, Ramamurthy VP \& Njar VC. Galeterone and VNPT55 induce proteasomal degradation of AR/AR-V7, induce significant apoptosis via cytochrome $\mathrm{c}$ release and suppress growth of castration resistant prostate cancer xenografts in vivo. Oncotarget $2015627440-27460$. (doi:10.18632/oncotarget.4578)

144 Handratta VD, Vasaitis TS, Njar VC, Gediya LK, Kataria R, Chopra P, Newman D, Farquhar R, Guo Z, Qiu Y, et al. Novel C-17-heteroaryl steroidal CYP17 inhibitors/antiandrogens: synthesis, in vitro biological activity, pharmacokinetics, and antitumor activity in the LAPC4 human prostate cancer xenograft model. Journal of Medicinal Chemistry 200548 2972-2984. (doi:10.1021/jm040202w)

145 Njar VC \& Brodie AM. Discovery and development of Galeterone (TOK-001 or VN/124-1) for the treatment of all stages of prostate cancer. Journal of Medicinal Chemistry 201558 2077-2087. (doi:10.1021/jm501239f)

146 Yu Z, Cai C, Gao S, Simon NI, Shen HC \& Balk SP. Galeterone prevents androgen receptor binding to chromatin and enhances degradation of mutant androgen receptor. Clinical Cancer Research 201420 4075-4085. (doi:10.1158/1078-0432.CCR-14-0292)

147 Purushottamachar P, Godbole AM, Gediya LK, Martin MS, Vasaitis TS, Kwegyir-Afful AK, Ramalingam S, Ates-Alagoz Z \& 
Njar VC. Systematic structure modifications of multitarget prostate cancer drug candidate galeterone to produce novel androgen receptor down-regulating agents as an approach to treatment of advanced prostate cancer. Journal of Medicinal Chemistry 201356 4880-4898. (doi:10.1021/jm400048v)

148 Liu C, Lou W, Armstrong C, Zhu Y, Evans CP \& Gao AC. Niclosamide suppresses cell migration and invasion in enzalutamide resistant prostate cancer cells via Stat3-AR axis inhibition. Prostate $2015 \mathbf{7 5}$ 1341-1353. (doi:10.1002/pros.23015)

149 Liu C, Lou W, Zhu Y, Nadiminty N, Schwartz CT, Evans CP \& Gao AC. Niclosamide inhibits androgen receptor variants expression and overcomes enzalutamide resistance in castration-resistant prostate cancer. Clinical Cancer Research 201420 3198-3210. (doi:10.1158/1078-0432.CCR-13-3296)

150 Liu C, Armstrong C, Zhu Y, Lou W \& Gao AC. Niclosamide enhances abiraterone treatment via inhibition of androgen receptor variants in castration resistant prostate cancer. Oncotarget $2016732210-32220$. (doi:10.18632/oncotarget.8493)

151 Zhang Y, Castaneda S, Dumble M, Wang M, Mileski M, Qu Z, Kim S, Shi V, Kraft P, Gao Y, et al. Reduced expression of the androgen receptor by third generation of antisense shows antitumor activity in models of prostate cancer. Molecular Cancer Therapeutics 201110 2309-2319. (doi:10.1158/1535-7163.MCT-11-0329)

152 Asangani IA, Dommeti VL, Wang X, Malik R, Cieslik M, Yang R, Escara-Wilke J, Wilder-Romans K, Dhanireddy S, Engelke C, et al.
Therapeutic targeting of BET bromodomain proteins in castrationresistant prostate cancer. Nature 2014510 278-282. (doi:10.1038/ nature13229)

153 James ND, Sydes MR, Clarke NW, Mason MD, Dearnaley DP, Spears MR, Ritchie AWS, Parker CC, Russell JM, Attard G, et al. Addition of docetaxel, zoledronic acid, or both to first-line longterm hormone therapy in prostate cancer (STAMPEDE): survival results from an adaptive, multiarm, multistage, platform randomised controlled trial. Lancet 2016387 1163-1177. (doi:10.1016/S01406736(15)01037-5)

154 Fizazi K, Tran N, Fein L, Matsubara N, Rodriguez-Antolin A, Alekseev BY, Özgüroğlu M, Ye D, Feyerabend S, Protheroe A, et al. Abiraterone plus prednisone in metastatic, castration-sensitive prostate cancer. New England Journal of Medicine 2017377 $352-360$

155 James ND, de Bono JS, Spears MR, Clarke NW, Mason MD, Dearnaley DP, Ritchie AWS, Amos CL, Gilson C, Jones RJ, et al. Abiraterone for prostate cancer not previously treated with hormone therapy. New England Journal of Medicine 2017377 338-351. (doi:10.1056/NEJMoa1702900)

156 You S, Knudsen BS, Erho N, Alshalalfa M, Takhar M, Al-Deen Ashab H, Davicioni E, Karnes RJ, Klein EA, Den RB, et al. Integrated classification of prostate cancer reveals a novel luminal subtype with poor outcome. Cancer Research 201676 4948-4958. (doi:10.1158/0008-5472.CAN-16-0902)

Received in final form 21 August 2017

Accepted 19 September 2017 http://www.endocrineconnections.org DOI: 10.1530/EC-17-0118
() 2017 The authors Published by Bioscientifica Ltd

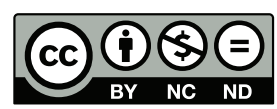

This work is licensed under a Creative Commons Attribution-NonCommercial-NoDerivatives 4.0 International License. 